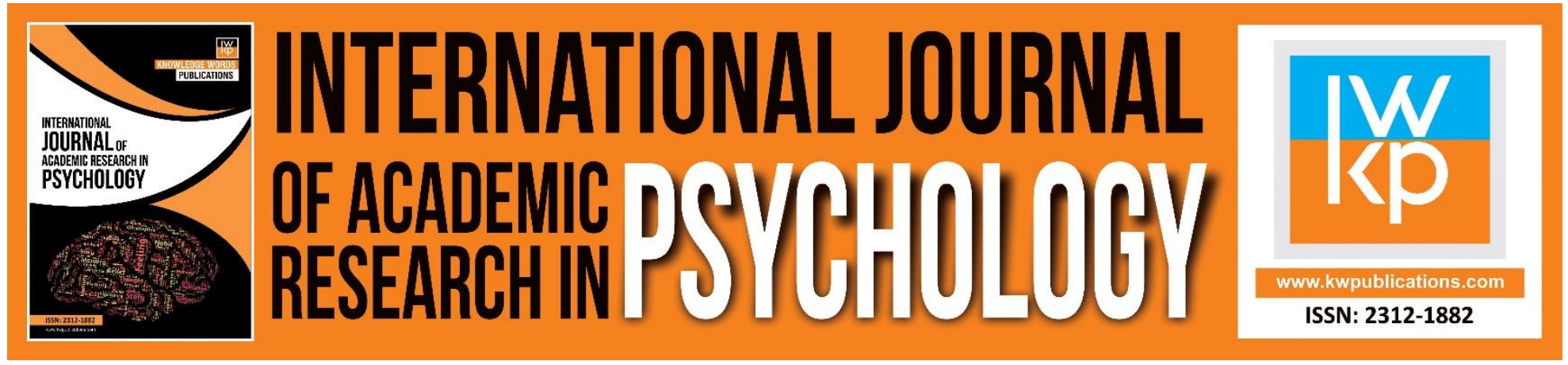

\title{
Interventions for Body Fat Reduction among Pakistani Women: A Randomized Control Trial Study
}

\author{
Muhammad Waseem Tufail, Rahmattullah Khan, Md. Azman Shahadan, \\ Muhammad Saleem
}

To Link this Article: http://dx.doi.org/10.46886/IJARP/v5-i1/2702

DOI:10.46886/IJARP/v5-i1/2702

Received: 11 March 2018, Revised: 16 May 2018, Accepted: 17 June 2018

Published Online: 30 August 2018

In-Text Citation: (Tufail et. al., 2018)

To Cite this Article: Tufail, M. W., Khan, R., Shahadan, M. A., Saleem, M. (2018). Interventions for Body Fat Reduction among Pakistani Women: A Randomized Control Trial Study. International Journal of Academic Research in Psychology. 5(1), 18-28.

Copyright: (c) 2018 The Author(s)

Published by Knowledge Words Publications (www.kwpublications.com)

This article is published under the Creative Commons Attribution (CC BY 4.0) license. Anyone may reproduce, distribute, translate and create derivative works of this article (for both commercial and non-commercial purposes), subject to full attribution to the original publication and authors. The full terms of this license may be seen at: http://creativecommons.org/licences/by/4.0/legalcode

Vol. 5, No. 1, 2018, Pg. 18 - 28

https://kwpublications.com/journals/journaldetail/IJARP

JOURNAL HOMEPAGE

Full Terms \& Conditions of access and use can be found at https://kwpublications.com/pages/detail/publication-ethics 


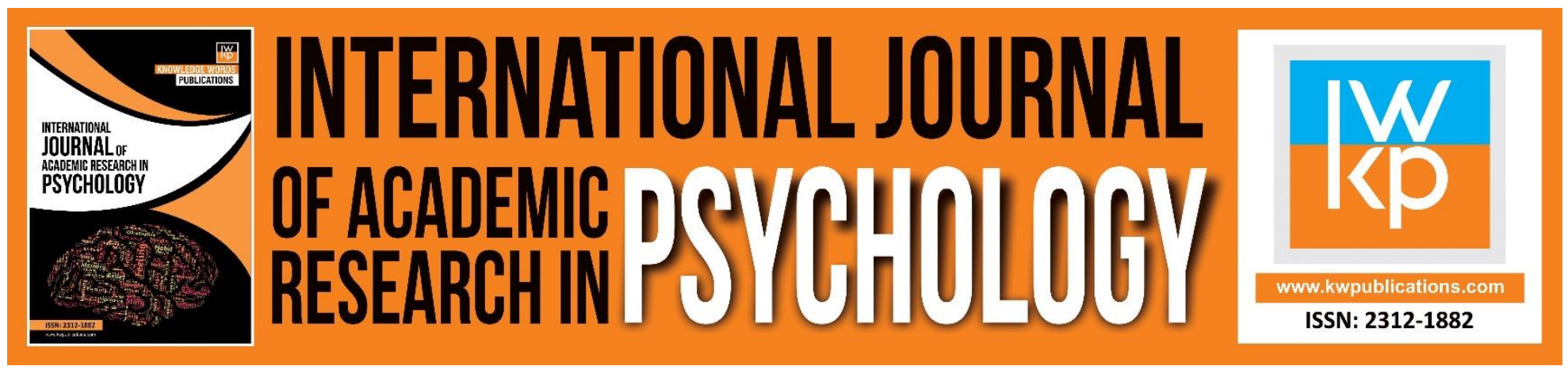

\title{
Interventions for Body Fat Reduction among Pakistani Women: A Randomized Control Trial Study
}

\author{
Muhammad Waseem Tufail', Rahmattullah Khan², Md. Azman \\ Shahadan $^{3}$, Muhammad Saleem ${ }^{4}$ \\ ${ }^{1} \mathrm{PhD}$ Candidate, Department of Psychology \& Counselling, Sultan Idris Education University, \\ Malaysia, ${ }^{2}$ Professor, Department of Psychology \& Counseling, Sultan Idris Education University, \\ Malaysia, ${ }^{3}$ Lecturer, Department of Psychology \& Counselling, Sultan Idris Education University, \\ Malaysia, ${ }^{4}$ Assistant Professor, Department of Applied Psychology, The Islamia University of \\ Bahawalpur, Pakistan.
}

\begin{abstract}
The burden of obesity is higher in Pakistani female, to overcome this burden effective treatment is desirable. The current study intends to provide effective intervention programs to reduce percent body fat among Pakistani women. Through randomized control trial study fourteen females ( $N=14$, $\mathrm{PBF}=30.28 \pm 3.24$ ) were recruited by employing penal data technique with simple randomization. The sample distributed into two equal groups from online randomization. The experimental group received 10-week sessions of modified cognitive behavior therapy (CBT) along with supervised and unsupervised exercise regimen, plus supervised diet management plan. As a contrast, the control group received 10-week sessions without offering standard treatment. The results found that the intervention group or experimental group significantly reduced percent body fat (-3.02) while control group reduced $(-0.37)$ within 10 weeks interventions, $\mathrm{F}=88.28, \mathrm{p}<.001^{* * *}, \eta_{\mathrm{p}}{ }_{\mathrm{p}}=.880$. Conclusively, the combination of CBT along with exercise regimen and diet plan is a most effective method to reduce percent body fat among obese women. The limitations and future directions are also discussed that can be a good contribution to the body of knowledge concerning obesity research.
\end{abstract}

Keywords: CBT, Exercise regimen, Diet Plan, PBF, Women, Obesity, Pakistan, Effective Interventions.

Introduction

Obesity defined as excess body fat that is valid reference to predict the obesity (National Institutes of Health, 1998; WHO, 1998), but unfortunately there is no cutoff point of body fat to classify obesity level or stage such as BMI cutoff point for different populations (Mascie-Taylor \& Goto, 2007), while greater than or equal to 30 considered as overweight and 35 body fat in

\footnotetext{
${ }^{1}$ PhD Candidate, Department of Psychology \& Counselling, Sultan Idris Education University, Malaysia.

${ }^{2}$ Professor, Department of Psychology \& Counseling, Sultan Idris Education University, Malaysia.
} 
INTERNATIONAL JOURNAL OF ACADEMIC RESEARCH IN PSYCHOLOGY

Vol. 5, No. 1, 2018, E-ISSN: 2312-1882 @ 2018 KWP

${ }^{3}$ Lecturer, Department of Psychology \& Counselling, Sultan Idris Education University, Malaysia.

${ }^{4}$ Assistant Professor, Department of Applied Psychology, The Islamia University of Bahawalpur, Pakistan.

women considered as obese (Lobman, Houtkooper, \& Going, 1997; Swainson et al., 2017; WHO, 1995), because BMI is not considered a good measure of obesity for Asian (Hingorjo, Syed, \& Qureshi, 2009). Therefore, percent body fat is considered a reliable and accurate tool to measure obesity (Juntaping et al., 2017), particularly for Pakistani population percent body fat is a better scale to measure obesity as compared to BMI (Fatima, Rehman, \& Chaudhry, 2014).

The South Asian have higher percent body fat (Misra et al., 2014) generally, while comparing with gender reference women significantly greater percent body fat as compared to male (Dias et al., 2016; Flegal et al., 2009; IIman, Zuhairini, \& Siddiq, 2016; Juntaping et al., 2017; Jackson et al., 2002), but comparing within same gender the Asian women have higher body fat as compared to white (Deurenberg, Yap, \& Van Staveren, 1998; Küpper et al., 1998; Wang et al., 1994), Chinese (Ntuk et al., 2014), Norwegian (Falch, \& Steihaug, 2000), and American women (Kamath et al., 1999).

In Pakistan, burden of obesity is higher in female (Fawwad et al., 2016; Tanzil, \& Jamali, 2016), because of Pakistani women have significantly higher percentage of body fat as compared to male (Akhter et al., 2015; Chachar et al., 2016; Hingorjo, Syed, \& Qureshi, 2009). Excessive body fat associated with mortality and morbidity (Koster et al., 2015; Mascie-Taylor \& Goto, 2007). A 22-years follow up study reported that excessive body fat is strongly associated with mortality rather than BMI (Heitmann et al., 2000).

Percent of body fat in excess amount adversely effected health and well-being (WHO, 1998; 2006) as well as significantly associated with risk factors for numerous chronic diseases (Barba et al., 2004; Dehghan \& Merchant, 2008), such as coronary heart disease, diabetes mellitus, dyslipidemia, hypertension (Chopra et al., 2013; Dentali, Sharma, \& Douketis, 2005; Ortega et al., 2016; Sharma, \& Chetty, 2005; Yusuf et al., 2004), type 2 diabetes (Bhatti et al., 2016; Gómez-Ambrosi et al., 2011), metabolic syndrome (Bosy-Westphal et al., 2006; Misra, \& Khurana, 2009), cardiometabolic dysregulation (Dervaux et al., 2008; Romero-Corral et al., 2009), early inflammation (Marques-Vidal et al., 2010), cancer (Britton et al., 2013), osteopenia, osteoporosis, non-spine fractures (Hsu et al., 2006), and hepatic steatosis (Falch, \& Steihaug, 2000).

Pakistani hospital study reported that higher percentage of body fat observed in female that is independent risk factors for ischemic heart disease as well as greater body fat women are suffering diabetes, hypertension (Chachar et al., 2016; Kitchlew, Chachar, \& Latif, 2017), type 2 diabetes (Akhter et al., 2015), gestational diabetes mellitus (Iqbal et al., 2007).

Finally, with respect the above scenario there is dire need to launch intervention program to reduce body fat for women specifically South Asian and Pakistani women because a review study explored that obesity prevention or management still not identified in developing countries including Pakistan (Poobalan \& Aucott, 2016). That is the reason to launch effective intervention plan for women by using multiple ways of treatment including modified cognitive behavior therapy along with exercise regimen and diet management while literature supported that percent body fat can be reduced through behavior modification (Harrigan et al., 2015), physical exercise (Longland et al., 2016; Pelemis et al., 2016; Sanal, Ardic, \& Kirac, 2013), and diet management (Karintrakul \& Angkatavanich, 2017), but combination of three methods (behavior modification, exercise, and diet management) are most effective to reduce percent body fat (Harrigan et al., 2015; Karintrakul \& Angkatavanich, 2017). 
INTERNATIONAL JOURNAL OF ACADEMIC RESEARCH IN PSYCHOLOGY

Vol. 5, No. 1, 2018, E-ISSN: 2312-1882 @ 2018 KWP

\section{Objective of the Study}

1. To gauge the efficacy of psycho-physical ways (modified cognitive behavior therapy, exercise management, and diet plan) to reduce percent body fat among Pakistani females.

Hypotheses of the study: It is hypothesized that...

H1: Experimental group loses more percent body fat as compared to control group among Pakistani females.

\section{Method}

\section{Participants and Procedure}

The current randomized control trial study recruited 14 adult females through penal sampling on the basis of a percent body fat (PBF $\geq 28$ ) from South-Punjab, Pakistan. Body composition analyzer (In-Body 370) was used to measure percent body fat. All participants equally distributed into two groups through online randomization after taking informed consent. The experimental group received multiple treatments as a form of modified cognitive behavior therapy-CBT (Motivational Interviewing, Self-monitoring \& problem solving) plus supervised physical activity or exercise (treadmill, aerobic exercise, \& unsupervised walking using a pedometer) plus supervised diet management for 10 -weeks (weekly session). While control group received no proper treatment, but engaged them in a group discussion during the session and evaluate their knowledge by asking questions in every week session until 10th-week sessions. After that percent body fat measured again at 10th week. After completing data collection, data were analyzed through SPSS (23.0), result displays intro standard tabulated form and discussion made on the basis of the result.

\section{Measurements}

The percent body fat was measured by a bioelectrical impedance analyzer (in-Body 370). This is composition analyzer is a valid and reliable digital instrument to measure the accurate percentage of body fat among obese people (Coleman et al., 2015; Lee et al., 2014).

\section{Data Analyses}

Data were analyzed through SPSS (23.0) by using descriptive statistics including mean and standard deviation for computing differences between experimental group and control group in terms of age, and percent body fat at baseline. Repeated measure ANOVA was employed for computing differences and changes in percent body fat between experimental group and control group from baseline to week 10 th.

\section{Ethical Considerations}

The current study considered and fulfilled almost all basic ethical concerns related to experimental in nature studies. Initially, study proposal approval taken from the ethical review committee. The current study fulfilled this step, by the recommendation of proposal evaluation penal from Institute of postgraduate study during proposal defense presentation. Penal sent study proposal to an ethical review committee that consists of five relevant national and international field experts. Study proposal amended according to filed experts' valuable suggestions. The next informed consent (written) taken from all participants. Privacy, autonomy, and confidentiality were maintained. Further, contamination was avoided among groups to arrange separate sessions in different timing and different days and to identify friends, and relatives who were included in the different groups. 
INTERNATIONAL JOURNAL OF ACADEMIC RESEARCH IN PSYCHOLOGY

Vol. 5, No. 1, 2018, E-ISSN: 2312-1882 @ 2018 KWP

Furthermore, risk and benefits considered as the completion of this study may provide benefits in the form of increased self-awareness regarding diet plan and exercise management. For some individuals, this self-awareness may produce momentary discomfort, or during an exercise session suffer fatigue. However, no appreciable adverse effects on participant's health or well-being expected. The main potential benefit to accrue from this study was decreased percent body fat as well as improved physical activity, and balanced diet.

\section{Results}

Table 1. Descriptive Statistics at base line

\begin{tabular}{ccccc}
\hline Measures & $\begin{array}{c}\text { Experimental Group } \\
\text { Mean }\end{array}$ & SD & $\begin{array}{c}\text { Control Group } \\
\text { Mean }\end{array}$ & SD \\
\hline Age & 31.0 & 6.27 & 26.43 & 5.19 \\
\% Body Fat & 30.14 & 3.80 & 30.42 & 2.87 \\
\hline
\end{tabular}

Table 1 shows descriptive statistics of age and percent body fat at baseline between experimental groups and control group. The result shows that mean age of the experimental group is 31.0 with standard deviation 6.27 while control group means age is 26.43 with standard deviation is 5.19 at baseline. The mean percent body fat of the experimental group is 30.14 with standard deviation is 3.80 while the mean percent of body fat of the control group is 30.42 with standard deviation is 2.87 that is the minor difference from the experimental group.

Table 2. Percent body fat from baseline to Post intervention

\begin{tabular}{ccccccc}
\hline Measures & $\begin{array}{c}\text { Baseline } \\
\text { Mean (SD) }\end{array}$ & $\begin{array}{c}\text { Ten Weeks } \\
\text { Mean (SD) }\end{array}$ & Change & $F$ & $\eta^{2}$ p & $p$-value \\
\hline $\begin{array}{rlcll}\text { \% Body Fat } \\
\text { Experimental }\end{array}$ & $30.14(3.80)$ & $27.12(3.93)$ & -3.02 & 88.28 & .880 & $<.001$ \\
Control & $30.42(2.87)$ & $30.05(2.82)$ & -0.37 & & & \\
\hline
\end{tabular}

Note: Computed using alpha $=.05, * p \leq .05, * * p \leq .01, * * * p \leq .001$

Table 2 shows loss of percent body fat between experimental group and control group from baseline to week 10th. A $2 \times 2$ repeated measure (group by time) ANOVA result reveal that experimental group reduced percent body fat (-3.02) within 10 weeks while control group reduced only $(-0.37)$ within the same time frame (see figure 1$)$. There was a significant interaction between treatment condition and time $\left(F=88.28, \eta^{2}{ }_{p}=.880, p=<.001^{* * *}\right)$ between experimental group and control group to lose percent body fat. 
INTERNATIONAL JOURNAL OF ACADEMIC RESEARCH IN PSYCHOLOGY

Vol. 5, No. 1, 2018, E-ISSN: 2312-1882 @ 2018 KWP

\section{Figure 1}

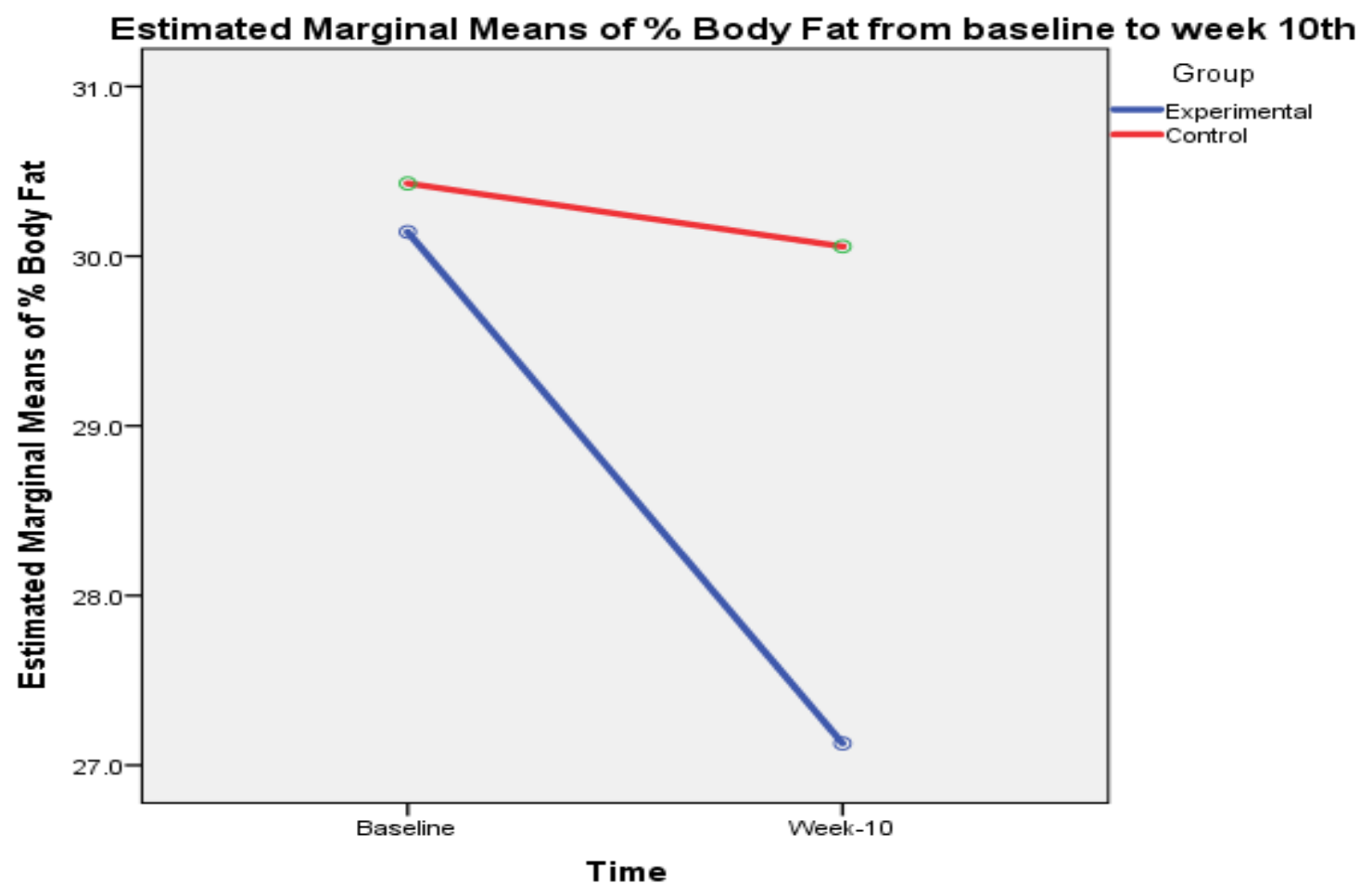

\section{Discussion}

The current study used psycho-physical intervention for percent body fat reduction among Pakistani obese women. Results indicated that experimental group (modified CBT + Exercise regimen + Diet plan) reduced percent body fat (-3.02) within 10th weeks and control group lose only (-0.37) within the same time duration. A recent similar study supported that through the restrictive nutritional plan, physical activity, along with counseling session intervention group of women can reduced percent body fat (-1.54) while control group increased (0.08) instead of reduced body fat within 12-weeks (Karintrakul \& Angkatavanich, 2017). While, another similar study supported that through combinations of behavior therapy, supervised exercise, and diet plan women reduced percent body fat (-3.3) within 6-months interventions (Harrigan et al., 2015). Another similar study findings show that through supervised moderate intensity exercises (3-times/week) and diet counseling intervention group of women reduced percent body fat (-2.5) within 12-weeks intervention while control group increased (0.4) instead of reduced within same stipulated time (Swisher et al., 2015).

A contrast study reported that through supervised high-intensity exercise (6days/week) along with supervised diet prescription higher protein intake group reduced body fat $(-4.8 \mathrm{~kg})$ while low protein intake group reduced $(-3.5 \mathrm{~kg})$ within 4-weeks intervention (Longland et. al., 2016). Furthermore, through supervised aerobic exercise training women reduced percent body fat $(-1.2)$ while with the combination of strength training reduced $(-1.6)$ but control group reduced only $(-0.1)$ within 16-weeks (Rossi et al., 2016). Another study supported that through supervised resistance (exercise) training women can reduce their body fat (-1.39) within 14 weeks while control group increased body fat (0.01) within the same time frame (Prabhakaran, Dowling, Branch, Swain, \& Leutholtz, 1999). 
Another study reported that after 5 months exercise training exercise group reduced percent body fat (-1.2) but control group increased (0.2) instead of reduced within same time duration (Boyden et al., 1993). A contrast study reported that there are no changes in percent body fat after 16 weeks resistance training (Hurley, 1988). A similar study supported that through moderate intensity aerobic exercise women can reduce percent body fat (-2.7) within 8-weeks (Pelemis et al., 2016). A similar study supported that through resistance and aerobic exercise training people can reduce body fat from (0 to -1.4 ) while control group reduced only (-0.4) within 10-weeks (Donges, Duffield, \& Drinkwater, 2010). Another study supported that through supervised aerobic and resistance exercise training (3times/week) women reduced percent body fat from (-0 to -3) while control group reduced only (-0.8) within 10-weeks (Donges \& Duffield, 2012). The study supported that through 12-weeks aerobic exercise people can reduced percent body fat $(-1.7)$ while the combination of aerobic and resistance exercise reduced percent body fat -5.2 (Sanal, Ardic, \& Kirac, 2013).

\section{Conclusion}

The psycho-physical intervention (combination of modified CBT, Exercise management, \& Diet plan) is effective for reducing obesity related body composition and to get a significant result within a short period of time between experimental group and control group. The current intervention is also effective particularly for body fat reduction among Pakistani obese women.

\section{Limitations and Future Directions}

There are some limitations of the study. The current study was limited to conduct 10th-week sessions without follow up sessions. The future studies should be an extended interventions time frame to get better results along with follow-up sessions to offer relapse prevention. Longitudinal studies should be conducted to measure long lasting changes in body composition. The current study was focused to reduce only one obesity diagnostic factor (percent body fat) without considering other diagnostic factors and contributing factors of obesity or covariates. The future studies should examine contributing factors of obesity and intervention studies should be focused other diagnostic factors to overcome the burden of obesity.

\section{Corresponding Author}

Muhammad Waseem Tufail

Department of Psychology \& Counselling Sultan Idris Education University, Malaysia

Email: waseemtufail.pk@gmail.com

\section{References}

Akhter, O., Fiazuddin, F., Shaheryar, A., Niaz, W., Siddiqui, D., Awan, S., \& Akhter, J. (2015). Central adiposity is significantly higher in female compared to male in Pakistani type 2 diabetes mellitus patients. Indian journal of endocrinology and metabolism, 19(1), 72.

Barba, C., Cavalli-Sforza, T., Cutter, J., \& Darnton-Hill, I. (2004). Appropriate body-mass index for Asian populations and its implications for policy and intervention strategies. The lancet, 363(9403), 157.

Bhatti, G. K., Bhadada, S. K., Vijayvergiya, R., Mastana, S. S., \& Bhatti, J. S. (2016). Metabolic syndrome and risk of major coronary events among the urban diabetic patients: North Indian Diabetes 
INTERNATIONAL JOURNAL OF ACADEMIC RESEARCH IN PSYCHOLOGY

Vol. 5, No. 1, 2018, E-ISSN: 2312-1882 @ 2018 KWP

and Cardiovascular Disease Study-NIDCVD-2. Journal of Diabetes and its Complications, 30(1), 72-78.

Bosy-Westphal, A., Geisler, C., Onur, S., Korth, O., Selberg, O., Schrezenmeir, J., \& Müller, M. J. (2006). Value of body fat mass vs anthropometric obesity indices in the assessment of metabolic risk factors. International journal of obesity, 30(3), 475.

Boyden, T. W., Pamenter, R. W., Going, S. B., Lohman, T. G., Hall, M. C., Houtkooper, L. B., ... \& Aickin, M. (1993). Resistance exercise training is associated with decreases in serum low-density lipoprotein cholesterol levels in premenopausal women. Archives of internal medicine, 153(1), 97-100.

Britton, K. A., Massaro, J. M., Murabito, J. M., Kreger, B. E., Hoffmann, U., \& Fox, C. S. (2013). Body fat distribution, incident cardiovascular disease, cancer, and all-cause mortality. Journal of the American College of Cardiology, 62(10), 921-925.

Chachar, A. Z. K., Javed, N., Fatima, A., Saleem, K., \& Qaisera, S. (2016). High Body Fat and Visceral Fat in Type II Diabetes Mellitus: a review of one hundred patients at Fatima Memorial Hospital. PJMHS, 10(3), 722-729.

Chopra, S. M., Misra, A., Gulati, S., \& Gupta, R. (2013). Overweight, obesity and related noncommunicable diseases in Asian Indian girls and women. European Journal of Clinical Nutrition, 67(7), 688.

Coleman, C. D., Kiel, J. R., Mitola, A. H., Langford, J. S., Davis, K. N., \& Arterburn, L. M. (2015). Effectiveness of a Medifast meal replacement program on weight, body composition and cardiometabolic risk factors in overweight and obese adults: a multicenter systematic retrospective chart review study. Nutrition journal, 14(1), 1.

Dehghan, M., \& Merchant, A. T. (2008). Is bioelectrical impedance accurate for use in large epidemiological studies. Nutrition Journal, 7(1), 26.

Dentali, F., Sharma, A. M., \& Douketis, J. D. (2005). Management of hypertension in overweight and obese patients: a practical guide for clinicians. Current Hypertension Reports, 7(5), 330-336.

Dervaux, N., Megnien, J. L., Chironi, G., \& Simon, A. (2008). Comparative associations of adiposity measures with cardiometabolic risk burden in asymptomatic subjects. Atherosclerosis, 201(2), 413-417.

Deurenberg, P., Yap, M., \& Van Staveren, W. A. (1998). Body mass index and percent body fat: a metaanalysis among different ethnic groups. International Journal of Obesity \& Related Metabolic Disorders, 22(12).

Deurenberg-Yap, M., Schmidt, G., van Staveren, W. A., \& Deurenberg, P. (2000). The paradox of low body mass index and high body fat percentage among Chinese, Malays and Indians in Singapore. International journal of obesity, 24(8), 1011.

Dias, H., Muc, M., Padez, C., \& Manco, L. (2016). Association of polymorphisms in 5-HTT (SLC6A4) and MAOA genes with measures of obesity in young adults of Portuguese origin. Archives of physiology and biochemistry, 122(1), 8-13.

Donges, C. E., \& Duffield, R. (2012). Effects of resistance or aerobic exercise training on total and regional body composition in sedentary overweight middle-aged adults. Applied Physiology, Nutrition, and Metabolism, 37(3), 499-509.

Donges, C. E., Duffield, R., \& Drinkwater, E. J. (2010). Effects of resistance or aerobic exercise training on interleukin-6, C-reactive protein, and body composition. Medicine and science in sports and exercise, 42(2), 304-313. 
INTERNATIONAL JOURNAL OF ACADEMIC RESEARCH IN PSYCHOLOGY

Vol. 5, No. 1, 2018, E-ISSN: 2312-1882 @ 2018 KWP

Falch, J. A., \& Steihaug, S. (2000). Vitamin D deficiency in Pakistani premenopausal women living in Norway is not associated with evidence of reduced skeletal strength. Scandinavian journal of clinical and laboratory investigation, 60(2), 103-109.

Fatima, S. S., Rehman, R., \& Chaudhry, B. (2014). Body mass index or body fat! Which is a better obesity scale for Pakistani population. JPMA, 64(11), 1225-8.

Fawwad, A., Siddiqui, I. A., Basit, A., Zeeshan, N. F., Shahid, S. M., Nawab, S. N., \& Siddiqui, S. (2016). Common variant within the FTO gene, rs9939609, obesity and type 2 diabetes in population of Karachi, Pakistan. Diabetes \& Metabolic Syndrome: Clinical Research \& Reviews, 10(1), 43-47.

Flegal, K. M., Shepherd, J. A., Looker, A. C., Graubard, B. I., Borrud, L. G., Ogden, C. L., ... \& Schenker, N. (2009). Comparisons of percentage body fat, body mass index, waist circumference, and waist-stature ratio in adults. The American journal of clinical nutrition, 89(2), 500-508.

Flegal, K. M., Shepherd, J. A., Looker, A. C., Graubard, B. I., Borrud, L. G., Ogden, C. L., \& Schenker, N. (2009). Comparisons of percentage body fat, body mass index, waist circumference, and waiststature ratio in adults. The American journal of clinical nutrition, 89(2), 500-508.

Gómez-Ambrosi, J., Silva, C., Galofré, J. C., Escalada, J., Santos, S., Gil, M. J., \& Frühbeck, G. (2011). Body adiposity and type 2 diabetes: increased risk with a high body fat percentage even having a normal BMI. Obesity, 19(7), 1439-1444.

Harrigan, M., Cartmel, B., Loftfield, E., Sanft, T., Chagpar, A. B., Zhou, Y., \& Irwin, M. L. (2015). Randomized trial comparing telephone versus in-person weight loss counseling on body composition and circulating biomarkers in women treated for breast cancer: The Lifestyle, Exercise, and Nutrition (LEAN) study. Journal of Clinical Oncology, 34(7), 669-676.

Heitmann, B. L., Erikson, H., Ellsinger, B. M., Mikkelsen, K. L., \& Larsson, B. (2000). Mortality associated with body fat, fat-free mass and body mass index among 60-year-old Swedish men-a 22-year follow-up. The study of men born in 1913. International journal of obesity, 24(1), 33.

Hingorjo, M. R., Syed, S., \& Qureshi, M. A. (2009). Overweight and obesity in students of a dental college of Karachi: lifestyle influence and measurement by an appropriate anthropometric index. JPMA. The Journal of the Pakistan Medical Association, 59(8), 528.

Hsu, Y. H., Venners, S. A., Terwedow, H. A., Feng, Y., Niu, T., Li, Z., \& Rosen, C. J. (2006). Relation of body composition, fat mass, and serum lipids to osteoporotic fractures and bone mineral density in Chinese men and women. The American journal of clinical nutrition, 83(1), 146-154.

Hurley, B. F., Hagberg, J. M., Goldberg, A. P., Seals, D. R., Ehsani, A. A., Brennan, R. E., \& Holloszy, J. O. (1988). Resistive training can reduce coronary risk factors without altering VO2max or percent body fat. Medicine and Science in Sports and Exercise, 20(2), 150-154.

Ilman, M., Zuhairini, Y., \& Siddiq, A. (2016). Correlation between Body Mass Index and Body Fat Percentage. Althea Medical Journal, 2(4), 575-578.

Iqbal, R., Rafique, G., Badruddin, S., Qureshi, R., Cue, R., \& Gray-Donald, K. (2007). Increased body fat percentage and physical inactivity are independent predictors of gestational diabetes mellitus in South Asian women. European journal of clinical nutrition, 61(6), 736.

Jackson, A. S., Stanforth, P. R., Gagnon, J., Rankinen, T., Leon, A. S., Rao, D. C., \& Wilmore, J. H. (2002). The effect of sex, age and race on estimating percentage body fat from body mass index: The Heritage Family Study. International journal of obesity, 26(6), 789.

Juntaping, K., Chittawatanarat, K., Prasitwattanaseree, S., Chaijaruwanich, J., \& Traisathit, P. (2017). Relationship between Height-Weight Difference Index and Body-Fat Percentage Estimated by Bioelectrical Impedance Analysis in Thai Adults. The Scientific World Journal, 2017. 
INTERNATIONAL JOURNAL OF ACADEMIC RESEARCH IN PSYCHOLOGY

Vol. 5, No. 1, 2018, E-ISSN: 2312-1882 @ 2018 KWP

Kamath, S. K., Hussain, E. A., Amin, D., Mortillaro, E., West, B., Peterson, C. T., \& Alekel, D. L. (1999). Cardiovascular disease risk factors in 2 distinct ethnic groups: Indian and Pakistani compared with American premenopausal women. The American journal of clinical nutrition, 69(4), 621631.

Karintrakul, S., \& Angkatavanich, J. (2017). A randomized controlled trial of an individualized nutrition counseling program matched with a transtheoretical model for overweight and obese females in Thailand. Nutrition research and practice, 11(4), 319-326.

Kitchlew, R., Chachar, A. Z. K., \& Latif, S. (2017). Body mass index; visceral fat and total body fat distribution and its relation to body mass index in clinical setting using bio-impedance body composition monitor. Professional Medical Journal, 24(2). 326-334

Koster, A., Murphy, R. A., Eiriksdottir, G., Aspelund, T., Sigurdsson, S., Lang, T. F., ... \& Harris, T. B. (2015). Fat distribution and mortality: The AGES-Reykjavik study. Obesity, 23(4), 893-897.

Küpper, J., Bartz, M., Schultink, J. W., Lukito, W., \& Deurenberg, P. (1998). Measurements of body fat in Indonesian adults: Comparison between a three-compartment model and widely used methods. Asia Pacific journal of clinical nutrition, 7, 49-54.

Lee, J.-M., Lee, W. J., Kim, H. C., Choi, W., Lee, J., Sung, K., . . Youm, Y. (2014). The Korean social life, health and aging project-health examination cohort. Epidemiology and health, 36, e2014003.

Lobman, T. G., Houtkooper, L., \& Going, S. B. (1997). Body Fat Measurement Goes High-Tech: Not All Are Created Equal. ACSM's Health \& Fitness Journal, 1(1), 30-35.

Longland, T. M., Oikawa, S. Y., Mitchell, C. J., Devries, M. C., \& Phillips, S. M. (2016). Higher compared with lower dietary protein during an energy deficit combined with intense exercise promotes greater lean mass gain and fat mass loss: a randomized trial. The American journal of clinical nutrition, 103(3), 738-746.

Marques-Vidal, P., Pécoud, A., Hayoz, D., Paccaud, F., Mooser, V., Waeber, G., \& Vollenweider, P. (2010). Normal weight obesity: relationship with lipids, glycaemic status, liver enzymes and inflammation. Nutrition, Metabolism and Cardiovascular Diseases, 20(9), 669-675.

Mascie-Taylor, N. C. G., \& Goto, R. (2007). Human variation and body mass index: a review of the universality of BMI cut-offs, gender and urban-rural differences, and secular changes. Journal of physiological anthropology, 26(2), 109-112.

Misra, A., \& Khurana, L. (2009). The metabolic syndrome in South Asians: epidemiology, determinants, and prevention. Metabolic syndrome and related disorders, 7(6), 497-514.

Misra, A., Ramchandran, A., Jayawardena, R., Shrivastava, U., \& Snehalatha, C. (2014). Diabetes in South Asians. Diabetic Medicine, 31(10), 1153-1162.

National Institutes of Health. (1998). Clinical guidelines on the identification, evaluation, and treatment of overweight and obesity in adults: the evidence report. Obes res, 6(2), 51S-209S.

Ntuk, U. E., Gill, J. M., Mackay, D. F., Sattar, N., \& Pell, J. P. (2014). Ethnic-specific obesity cutoffs for diabetes risk: cross-sectional study of 490,288 UK biobank participants. Diabetes care, 37(9), 2500-2507.

Ortega, F. B., Sui, X., Lavie, C. J., \& Blair, S. N. (2016, April). Body mass index, the most widely used but also widely criticized index: would a criterion standard measure of total body fat be a better predictor of cardiovascular disease mortality. In Mayo Clinic Proceedings (Vol. 91, No. 4, pp. 443-455). Elsevier.

Pelemis, V. M., Macura, M., Andrevski-Krivokuća, N., Ujsasi, D., Pelemiš, M., \& Lalić, S. (2016). The influence of aerobic training on the biochemical and physical parameters of obese women. Facta Universitatis, Series: Physical Education and Sport, 217-228. 
INTERNATIONAL JOURNAL OF ACADEMIC RESEARCH IN PSYCHOLOGY

Vol. 5, No. 1, 2018, E-ISSN: 2312-1882 @ 2018 KWP

Poobalan, A., \& Aucott, L. (2016). Obesity among young adults in developing countries: a systematic overview. Current obesity reports, 5(1), 2-13.

Prabhakaran, B., Dowling, E. A., Branch, J. D., Swain, D. P., \& Leutholtz, B. C. (1999). Effect of 14 weeks of resistance training on lipid profile and body fat percentage in premenopausal women. British Journal of Sports Medicine, 33(3), 190-195.

Romero-Corral, A., Somers, V. K., Sierra-Johnson, J., Korenfeld, Y., Boarin, S., Korinek, J., ... \& LopezJimenez, F. (2009). Normal weight obesity: a risk factor for cardiometabolic dysregulation and cardiovascular mortality. European Heart Journal, 31(6), 737-746.

Rossi, F. E., Fortaleza, A. C., Neves, L. M., Buonani, C., Picolo, M. R., Diniz, T. A., ... \& Junior, I. F. F. (2016). Combined training (aerobic plus strength) potentiates a reduction in body fat but demonstrates no difference on the lipid profile in postmenopausal women when compared with aerobic training with a similar training load. The Journal of Strength \& Conditioning Research, 30(1), 226-234.

Sanal, E., Ardic, F., \& Kirac, S. (2013). Effects of aerobic or combined aerobic resistance exercise on body composition in overweight and obese adults: gender differences. A randomized intervention study. Eur J Phys Rehabil Med, 49(1), 1-11.

Sharma, A. M., \& Chetty, V. T. (2005). Obesity, hypertension and insulin resistance. Acta diabetologica, 42(1), s3-s8.

Swainson, M. G., Batterham, A. M., Tsakirides, C., Rutherford, Z. H., \& Hind, K. (2017). Prediction of whole-body fat percentage and visceral adipose tissue mass from five anthropometric variables. PloS one, 12(5), e0177175.

Swisher, A. K., Abraham, J., Bonner, D., Gilleland, D., Hobbs, G., Kurian, S., ... \& Vona-Davis, L. (2015). Exercise and dietary advice intervention for survivors of triple-negative breast cancer: effects on body fat, physical function, quality of life, and adipokine profile. Supportive Care in Cancer, 23(10), 2995-3003.

Tanzil, S., \& Jamali, T. (2016). Obesity, an emerging epidemic in Pakistan-a review of evidence. Journal of Ayub Medical College Abbottabad, 28(3), 597-600.

Wang, J., Thornton, J. C., Russell, M., Burastero, S., Heymsfield, S., \& Pierson, R. N. (1994). Asians have lower body mass index (BMI) but higher percent body fat than do whites: comparisons of anthropometric measurements. The American journal of clinical nutrition, 60(1), 23-28.

Wang, J., Thornton, J. C., Russell, M., Burastero, S., Heymsfield, S., \& Pierson, R. N. (1994). Asians have lower body mass index (BMI) but higher percent body fat than do whites: comparisons of anthropometric measurements. The American journal of clinical nutrition, 60(1), 23-28.

WHO. (1998). Obesity: preventing and managing the global epidemic. Report on a WHO consultation on Obesity, Geneva 3-5 June 1997. World Health Organization, Geneva

World Health Organization. (1995). Physical Status: The use and interpretation of anthropometry. Technical Report Series 854, Geneva.

World Health Organization. (2006). Global strategy on diet, physical activity and health: a framework to monitor and evaluate implementation. Fact sheet no. 311.

Yusuf, S., Hawken, S., Ôunpuu, S., Dans, T., Avezum, A., Lanas, F., ... \& Lisheng, L. (2004). Effect of potentially modifiable risk factors associated with myocardial infarction in 52 countries (the INTERHEART study): case-control study. The lancet, 364(9438), 937-952. 